\title{
Increased degradation of copepod faecal pellets by co-acting dinoflagellates and Centropages hamatus
}

\author{
Camilla Svensen $^{1, *}$, Nathalie Morata ${ }^{2}$, Marit Reigstad ${ }^{1}$ \\ ${ }^{1}$ Faculty of Biosciences, Fisheries and Economics, UiT The Arctic University of Norway, 9037 Tromsø, Norway \\ ${ }^{2}$ LEMAR, CNRS UMR 6539, 29280 Plouzané, France
}

\begin{abstract}
Copepod faecal pellets (FP) are carbon-rich particles possibly of great importance for the biological pump. However, most FP are degraded within the euphotic zone, by processes not yet fully understood. In a series of experiments conducted in Gullmarsfjorden, Sweden, we investigated degradation rates $\left(r, \mathrm{~d}^{-1}\right)$ of large copepod FP (average length and width: $466 \times 62 \mu \mathrm{m}$ ) exposed to the following treatments: (1) a natural assemblage of dinoflagellates $\left(96 \mathrm{\mu g} \mathrm{C} \mathrm{l}^{-1}\right),(2)$ the copepod Centropages hamatus $\left(10\right.$ copepods $\left.\mathrm{l}^{-1}\right)$ and (3) a combination of the 2 treatments. FP incubated in filtered seawater served as a control and a measure of degradation by pellet-associated bacteria. Bacterial degradation of FP was low, only $0.04 \mathrm{~d}^{-1}$, while the natural community of dinoflagellates degraded FP at a rate of $0.18 \mathrm{~d}^{-1}$. FP incubated with $C$. hamatus were degraded at a rate of $0.6 \mathrm{~d}^{-1}$, but degradation was faster when the dinoflagellates and C. hamatus acted together. The resulting degradation rate $\left(1.12 \mathrm{~d}^{-1}\right)$ was higher than the sum of the degradation rates measured under each individual condition (bacteria + dinoflagellates $+C$. hamatus). We suggest an interactive effect of dinoflagellates and copepods acting together-that the copepods were mechanically breaking up large FP, making the FP more available for further degradation by the dinoflagellates. This finding may have implications for understanding FP fluxes and carbon export in the ocean and points to a more complex 'coprophagous filter' (sensu González \& Smetacek 1994; Mar Ecol Prog Ser 113:233-246) than originally suggested.
\end{abstract}

KEY WORDS: Centropages hamatus $\cdot$ Dinoflagellates $\cdot$ Faecal pellet $\cdot$ Fecal pellet $\cdot$ Degradation rates $\cdot$ Carbon flux $\cdot$ Retention

Resale or republication not permitted without written consent of the publisher

\section{INTRODUCTION}

Carbon-rich particles sinking from the euphotic zone to the deeper, less productive parts of the ocean are important elements of the biological pump. The efficiency of this pump is related to primary productivity and degradation of organic material. Copepod faecal pellets (FP) are possibly important contributors to the downward flux of carbon, and mechanisms for FP degradation have received increased attention during the last decade (Poulsen \& Kiørboe 2005, Reigstad et al. 2005, Iversen \& Poulsen 2007, Ploug et al. 2008, Svensen et al. 2012). However, the contribution of FP to the downward flux of carbon is highly variable both seasonally (Wexels Riser et al. 2010) and geographically (Wexels Riser 2007). The fate of FP as they pass through the water column is still not well understood and has been suggested to depend on several possible mechanisms: mechanical stress, coprophagy (ingestion of pellets), coprohexy (fragmentation of pellets) and microbial degradation (Jumars et al. 1989, Lampitt et al. 1990, Noji 1991, Hansen et al. 1996). Degradation by mechanical stress can depend on the pellet structure, as grazers fed with e.g. diatoms have been found to pro- 
duce FP that are more robust than those produced on a flagellate diet (Hansen et al. 1996).

While cyclopoid copepods of the genus Oithona have for some time been considered the main grazers on FP (González \& Smetacek 1994, Svensen \& Nejstgaard 2003), more recent studies suggest that this is not always the case and that other flux-feeding organisms must also be taken into consideration (Reigstad et al. 2005, Iversen \& Poulsen 2007). For instance, protozooplankton are able to use FP as a direct food source (Jacobsen \& Azam 1984, Noji 1991, Turner 2002, Poulsen \& Kiørboe 2006, Poulsen \& Iversen 2008). Bacteria originating from the copepod's gut and pelagic bacteria can also degrade FP (Turner 1979, Gowing \& Silver 1983, Jacobsen \& Azam 1984, Hansen \& Bech 1996).

In temperate areas, like the North Sea, plankton organisms $<200 \mu \mathrm{m}$ were the main degraders of medium-sized copepod pellets (Poulsen \& Kiørboe 2006), and dinoflagellates appear to play a key role (Poulsen \& Iversen 2008). Conversely, in a study conducted in northern Norway, protozooplankton alone did not seem capable of degrading large copepod FP within relevant time-frames, although in concert with filter-feeding copepods, the degradation was significant (Svensen et al. 2012).

In the present study, we tested the rates of degradation of large copepod FP achieved by different naturally occurring organisms in a temperate zone summer situation in Gullmarsfjorden, southwestern Sweden. The pellets used in the experiments were produced by Calanus spp. The pellets were exposed for $48 \mathrm{~h}$ to the following degradation conditions: (1) a natural assemblage of dinoflagellates, (2) the copepod Centropages hamatus and (3) a combination of the two treatments. FP incubated in filtered seawater served as a control and also provided a measure of degradation by pellet-associated micro-organisms quantified through carbon-specific respiration rates.

\section{MATERIALS AND METHODS}

\section{Sampling, faecal pellet production and analyses}

Copepods were collected with a vertical tow (100 to $0 \mathrm{~m}$ ) in Gullmarsfjorden, southwestern Sweden, on 18 August 2010, using a zooplankton net equipped with $500 \mu \mathrm{m}$ mesh size and a non-filtering cod-end. The content of the cod-end was gently diluted in a 10 l cooling box with surface water. In the laboratory, individuals of Calanus spp. copepodid Stage V and females were sorted under a dissecting microscope and incubated in filtered seawater (FSW) overnight in a temperature-controlled room at ambient temperature $\left(17^{\circ} \mathrm{C}\right)$ to allow the copepods to empty their guts. C. helgolandicus dominated the Calanus population, although some $C$. finmarchicus were also present. Therefore, our experimental copepods most likely contained a mix of the 2 species and will henceforth be referred to as Calanus for simplicity. To produce FP for the experiments, 250 to 300 copepods were transferred to each of two 51 beakers filled with FSW and fed a mixture of cultured Rhodomonas sp. and Thalassiosira weissflogi at a final concentration of $\sim 500 \mu \mathrm{g} \mathrm{C}^{-1}$. The copepods were incubated in the dark at $17^{\circ} \mathrm{C}$ and were allowed to feed overnight, after which FP were siphoned off from the bottom of the beakers into smaller vials for sorting. Intact FP were collected under a dissecting microscope with a fine-mouthed pipette and rinsed 3 times in FSW before being used in the experiments. FP were kept cool during sorting by keeping the beakers on ice, and total handling time was $<6 \mathrm{~h}$.

From the batch of FP produced for the degradation experiment, 50 FP were measured (length and width) under a stereomicroscope (100× enlargement) to obtain a measure of FP volume (Table 1). In addition, 400 FP were collected for analysis of organic $C$ and $\mathrm{N}$ content as described at the end of this section. Data on FP volume and C content permitted determination of the carbon:volume conversion factor used in this experiment (Table 1).

FP degradation rates under the different conditions after $48 \mathrm{~h}$ of incubation were calculated from the expression $N_{t}=N_{0} \mathrm{e}^{-r t}$, where $r$ is degradation rate $\left(\mathrm{d}^{-1}\right), N_{t}$ is FP concentration $\left(\mu \mathrm{g} \mathrm{Cl}^{-1}\right)$ at the end of the experiment, $N_{0}$ is FP concentration at the start of the experiment $\left(\mu \mathrm{g} \mathrm{C}^{-1}\right)$, and $t$ is incubation time (d).

Samples for chl a (total and the $>11 \mu \mathrm{m}$ fraction) were filtered onto $\mathrm{GF} / \mathrm{F}$ filters and extracted in ethanol for $24 \mathrm{~h}$ in $96 \%$ ethanol (Parsons et al. 1984).

Table 1. Properties of faecal pellets (FP) used in the degradation and respiration experiment. Length, width, volume, carbon content, nitrogen content, carbon:nitrogen (C:N) ratio and carbon:volume $(\mathrm{C}: \mathrm{V})$ ratio of pellets produced by Calanus finmarchicus and C. helgolandicus feeding on Rhodomonas sp. (mean $\pm \mathrm{SD}, \mathrm{n}=400$ )

\begin{tabular}{|ll}
\hline Length $(\mu \mathrm{m})$ & $466 \pm 90$ \\
Width $(\mu \mathrm{m})$ & $62 \pm 7$ \\
Volume $\left(\mu \mathrm{m}^{3}\right)$ & $1.45 \times 10^{6} \pm 0.52 \times 10^{6}$ \\
Carbon $\left(\mu \mathrm{C} \mathrm{FP}^{-1}\right)$ & $0.17 \pm 0.017$ \\
Nitrogen $\left.(\mu \mathrm{g} \mathrm{N} \mathrm{FP})^{-1}\right)$ & $0.018 \pm 0.002$ \\
$\mathrm{C}: \mathrm{N}$ & $11.3 \pm 2.33$ \\
$\mathrm{C}: \mathrm{V}\left(\mu \mathrm{C} \mathrm{mm}^{-3}\right)$ & 115.1 \\
\hline
\end{tabular}


Chl a concentrations were measured on a Turner Designs fluorometer. Samples for particulate organic carbon (POC) and particulate organic nitrogen (PON) were filtered in duplicates onto pre-combusted GF/F filters, frozen $\left(-20^{\circ} \mathrm{C}\right)$ and analysed on a Leeman Lab 440 elemental analyser. Samples were fumed with concentrated $\mathrm{HCl}$ prior to analyses to remove inorganic carbon. Samples for analyses of POC and PON content of copepod FP were treated in the same way as the POC/PON samples from the water column.

\section{Water for incubation}

Water for the degradation experiment ('dinoflagellate treatment') was collected in Gullmarsfjorden at $5 \mathrm{~m}$ depth using 301 Niskin bottles. At the start of the experiment $\left(\mathrm{T}_{0}\right)$, samples were taken for analyses of chl a (total and $>11 \mu \mathrm{m}$ ), POC and PON. Incubation water was filtered through a $180 \mu \mathrm{m}$ mesh to remove large grazers. From the incubation water, a sub-sample of $600 \mathrm{ml}$ was checked for 'background' FP by running it through a $10 \mu \mathrm{m}$ mesh, which was then examined visually in a dissecting microscope. No FP were found in the incubation water, and the entire sample was preserved with acid Lugol's solution ( $2 \%)$ for identification and enumeration of the plankton community in the size range 10 to $180 \mu \mathrm{m}$. A $100 \mathrm{ml}$ sub-sample was allowed to sediment in Utermöhl chambers, and its content was identified to group and species level under an inverted microscope. Cells (dominated by dinoflagellates) were counted, measured and carbon content was calculated by applying the conversion factor pg C cell ${ }^{-1}=$ $0.760 \times$ volume $^{0.819}$ (Menden-Deuer \& Lessard 2000). A few ciliates (Strombidium spp.) and copepod nauplii were present in the sample but were too few to be quantified accurately.

\section{Faecal pellet degradation experiment}

The experiment was designed to investigate degradation of copepod FP by the natural community of microbes < $180 \mu \mathrm{m}$, the copepod Centropages hamatus and the combined effect of microorganisms and copepods. Due to the dominance of dinoflagellates in the incubation water collected at the depth of the chl a max, we will henceforth refer to this as the 'dinoflagellate treatment', even though dinoflagellates were not originally the specific target-organisms in the treatment involving microbes $<180 \mu \mathrm{m}$.
The copepods used in the degradation experiments, Centropages hamatus, are capable of switching between filter-feeding and ambush-feeding (Tiselius \& Jonsson 1990, Saage et al. 2009). Its feeding current is relatively strong, and the diet is described as omnivorous but with a large fraction of phytoplankton (Conley \& Turner 1985, Saage et al. 2009). The faecal pellets of $C$. hamatus are smaller than those of Calanus spp. (length: 113-242 $\mu \mathrm{m}$, width: 45-50 $\mu \mathrm{m}_{i}$ J. Urban Rich at www.zfpguide. com).

We added $80 \mathrm{FP}\left(13.6 \mu \mathrm{g} \mathrm{C}\right.$ bottle ${ }^{-1}$ or $27.2 \mu \mathrm{g} \mathrm{C} \mathrm{l}^{-1}$, average length $466 \mu \mathrm{m}$, and width $62 \mu \mathrm{m}$ ) produced by Calanus spp. to a total of 16 bottles each containing $500 \mathrm{ml}$ and investigated FP degradation by $48 \mathrm{~h}$ exposure to the following treatments: (1) naturally occurring dinoflagellates (i.e. water collected from the chl a maximum screened through $180 \mu \mathrm{m}$ mesh; $96 \mu \mathrm{g} \mathrm{C}^{-1}$ ), (2) the copepod C. hamatus in FSW (5 copepods per bottle, 10 copepods $\mathrm{l}^{-1}$ ) and (3) a combination of dinoflagellates and $C$. hamatus. FP incubated in FSW (0.22 $\mu \mathrm{m}$ filter) served as controls and provided a measure of FP degradation by bacteria associated with the FP. All 4 treatments, including the controls, were replicated in 4 replicate bottles for each treatment. All 16 of these bottles were incubated simultaneously on a slowly rotating plankton wheel $(1 \mathrm{rpm})$ at ambient temperature $\left(17^{\circ} \mathrm{C}\right)$ and in darkness. After $48 \mathrm{~h}$, the experiment was terminated by gently concentrating the content of each bottle over a $10 \mu \mathrm{m}$ meshed sieve submerged in FSW. The concentrated sample was preserved with formalin ( $2 \%$ final concentration), allowed to sediment in Utermöhl chambers for $24 \mathrm{~h}$ and analysed using an inverted microscope (Leica DM IL) at 100× magnification. The estimate of FP degradation rates is highly sensitive to the precision of FP quantifications after incubation. All FP, intact and fragmented, were therefore counted and measured (length and width) for volume estimation. FP were converted from volume to carbon using a volume:carbon factor of 115.1 $\mu \mathrm{g} \mathrm{C} \mathrm{mm} \mathrm{mm}^{-3}$ (Table 1), which was obtained by direct carbon analyses and volume measurements of intact FP.

\section{Faecal pellet carbon demand through microbial respiration}

To determine FP degradation by various microorganisms, 2 complementary methods can be used: respiration measurements (Hansen et al. 1996) and microscopic counts (Svensen et al. 2012). Carbon 
degradation of copepod FP through bacterial and dinoflagellate respiration (as an indicator of overall metabolism) was measured by 5 replicate incubations of $30 \mathrm{FP}$ in each of $4 \mathrm{ml}$ glass microchamber vials filled with either $0.2 \mu \mathrm{m}$ FSW or $<180 \mu \mathrm{m}$ chl a max water (collected from the depth of the chl a maximum; i.e. dinoflagellate treatment) similar to the incubation water in the FP-degradation experiments. The vials were sealed with glass stoppers in such a way as to eliminate any headspace bubbles. While incubating FP in $0.2 \mu \mathrm{m}$ FSW provides a measure of the carbon demand due to bacteria present in the FP matrix, the incubation with $<180 \mu \mathrm{m}$ chl a max water gives a measure of the carbon demand of both the bacterial pellet matrix and the free bacteria, algae and protozooplankton present in the water. The glass stopper had a capillary hole $(<0.7 \mathrm{~mm} \times 13 \mathrm{~mm})$ allowing the oxygen sensor to pass unimpeded but effectively preventing the diffusion of oxygen (oxygen micro-respiration chambers, Unisense AS; Aarhus, Denmark). Vials were placed in the dark in a submerged plankton wheel at $17^{\circ} \mathrm{C}$ rotating at $1 \mathrm{rpm}$ to keep the material in suspension (see e.g. Reigstad et al. 2005). Oxygen was monitored every 6 to $8 \mathrm{~h}$ for $48 \mathrm{~h}$ with an oxygen sensor microsensor (Unisense AS) and never dropped below 15 to $20 \%$ (Renaud et al. 2007). Oxygen consumption rates were calculated as the (negative) slope of the regression line between oxygen concentration and time, blank values were subtracted, and rates were converted to carbon demand, assuming a respiration factor of $1 \mathrm{~mol} \mathrm{O}_{2}: 1 \mathrm{~mol} \mathrm{CO}_{2}$ (Ploug et al. 2008). Carbon-specific respiration represents the carbon demand $\left(\mu \mathrm{C} \mathrm{C} \mathrm{d}^{-1}\right)$ per FP carbon contents $\left(\mu \mathrm{FPC}^{-1}\right.$ ) and is expressed as daily degradation rate, $r$. Assuming a constant ratio between FP volume and carbon content, C-specific respiration was used as an indicator of degradation.

\section{RESULTS}

\section{Composition of the microbial community in the 10-180 $\mu \mathrm{m}$ size fraction}

The incubation water containing the microbial community, including dinoflagellates, was collected at the depth of the chl a maximum, i.e. at $5 \mathrm{~m}$. Concentrations of POC, PON and chl a were high, and cells > $11 \mu \mathrm{m}$ made up half of the chl a concentration (Table 2). As the microscopy sample
Table 2. Initial concentrations $\left(\mathrm{T}_{0}\right)$ of chl $a$, particulate organic carbon (POC), particulate organic nitrogen (PON) and carbon:nitrogen ratio $(\mathrm{C}: \mathrm{N})$ in incubation water (average of 2 samples per parameter). The incubation water was collected at $5 \mathrm{~m}$ depth in Gullmarsfjorden 19 August 2010 and pre-filtered at $180 \mu \mathrm{m}$

\begin{tabular}{|lcccc|}
\hline $\begin{array}{l}\text { Chl a total } \\
\left(\mu \mathrm{g} \mathrm{l}^{-1}\right)\end{array}$ & $\begin{array}{c}\text { Chl } a>11 \mu \mathrm{m} \\
\left(\mu \mathrm{g} \mathrm{l}^{-1}\right)\end{array}$ & $\begin{array}{c}\text { POC } \\
\left(\mu \mathrm{g} \mathrm{l}^{-1}\right)\end{array}$ & $\begin{array}{c}\text { PON } \\
\left(\mu \mathrm{g} \mathrm{l}^{-1}\right)\end{array}$ & C:N \\
\hline 2.8 & 1.4 & 466 & 64 & 8.5 \\
\hline
\end{tabular}

from the incubation water had been sieved through a $10 \mu \mathrm{m}$ mesh to check for suspended FP in the full bottle volume of $600 \mathrm{ml}$, autotrophic cells $<10 \mu \mathrm{m}$ were not quantified. The incubation water was completely dominated by dinoflagellates $(>10 \mu \mathrm{m})$, with a total concentration of $96 \mu \mathrm{C} \mathrm{C}^{-1}$ (Table 3). Thecate dinoflagellates made up the largest part $\left(93 \mu \mathrm{g} \mathrm{C} \mathrm{l}^{-1}\right)$, with large cells of Prorocentrum sp. and Ceratium sp. contributing roughly 30 and $26 \%$, respectively. Dinophysis sp. and Protoperidinium sp. contributed 18 and $15 \%$, respectively, of the total thecate dinoflagellates, and the cells composing the remainder of the biomass were not identified to genus (Table 3). A few Strombidium sp., rotifers and copepod nauplii were also encountered in the incubation water, although in such low counts (<15 in $150 \mathrm{ml}$ sample) that quantification was not feasible.

\section{Faecal pellet degradation}

The average width of the FP used in the degradation experiment was $62 \pm 7 \mu \mathrm{m}$ (Table 1) and remained unchanged after $48 \mathrm{~h}$ incubation $\left(t_{48}\right)$, irre-

Table 3. Composition and concentration of organisms $>10 \mu \mathrm{m}$ and $<180 \mu \mathrm{m}$ in the incubation water. In addition to the dinoflagellates, ciliates and copepod nauplii were also present in the incubation water, although in numbers too low for accurate quantification. Equivalent spherical diameter (ESD) is given as average $\pm \mathrm{SD}$

\begin{tabular}{|c|c|c|c|c|c|}
\hline & Cells $\mathrm{l}^{-1}$ & $\mu \mathrm{g} \mathrm{C} l^{-1}$ & $\begin{array}{l}\mathrm{ESD} \\
(\mu \mathrm{m})\end{array}$ & $\begin{array}{c}\% \text { of } \\
\text { cells } l^{-1}\end{array}$ & $\begin{array}{c}\% \text { of } \mu \mathrm{g} \\
\mathrm{C}^{-1}\end{array}$ \\
\hline Athecate unidentified & 1640 & 3.3 & $28 \pm 11$ & 28 & 3 \\
\hline Thecate unidentified & 920 & 10.8 & $57 \pm 23$ & 16 & 11 \\
\hline Dinophysis spp. & 480 & 16.8 & $93 \pm 25$ & 8 & 17 \\
\hline Protoperidinium spp. & 720 & 13.6 & $71 \pm 24$ & 12 & 14 \\
\hline Ceratium spp. & 480 & 24.0 & $109 \pm 26$ & 28 & 25 \\
\hline Prorocentrum spp. & 1640 & 27.5 & $71 \pm 13$ & 28 & 29 \\
\hline Total athecate dinoflagellates & 1640 & 3.0 & & 28 & 3 \\
\hline Total thecate dinoflagellates & 4240 & 93.0 & & 72 & 97 \\
\hline Total dinoflagellates & 5880 & 96 & & & \\
\hline
\end{tabular}




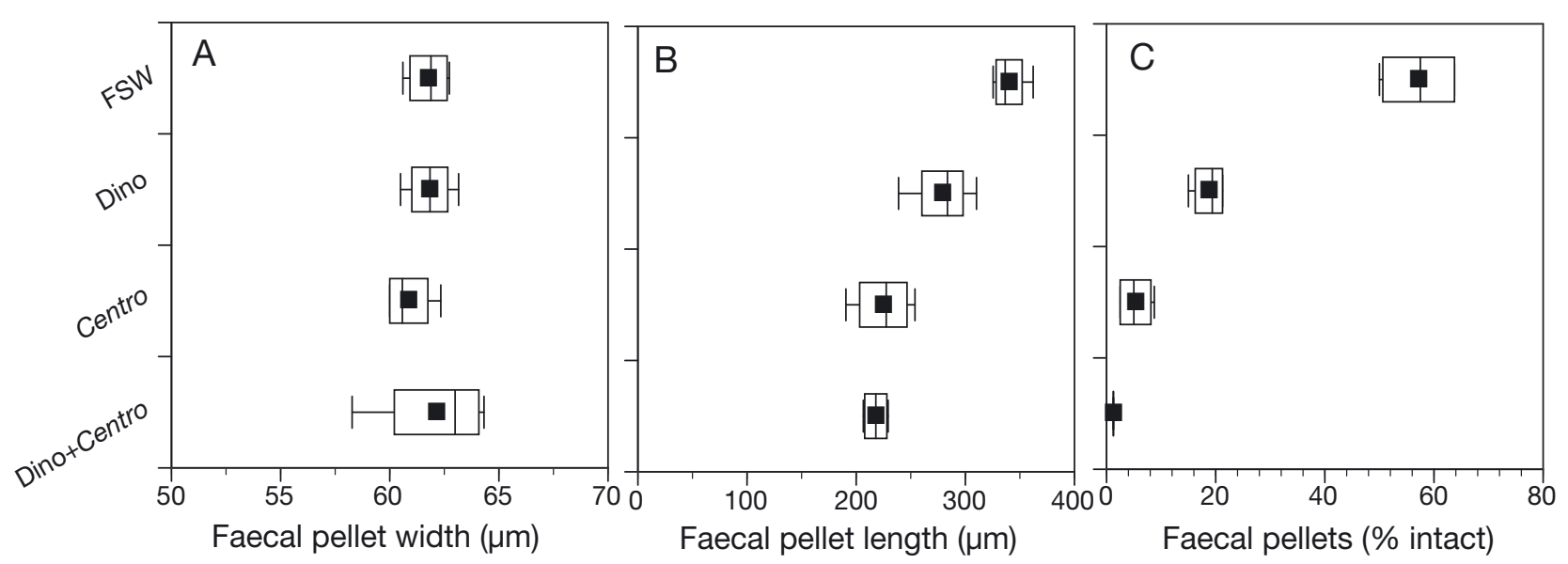

Fig. 1. (A) Calanus spp. faecal pellet width $(\mu \mathrm{m})$, (B) FP length $(\mu \mathrm{m})$ and $(\mathrm{C})$ percentage intact pellets after $48 \mathrm{~h}$ incubation. Eighty FP were exposed to 4 different treatment conditions: filtered seawater (FSW), dinoflagellates (Dino), Centropages hamatus (Centro) and dinoflagellates + C. hamatus (Dino+Centro). Box limits: 1st and 3rd quartiles; mid-line: median; filled square: mean; whiskers: outliers

spective of treatment (Fig. 1A). In contrast, the average length of FP at $t_{48}$ depended on the treatment group. The longest FP were found in the control (FSW) and the shortest in the 2 treatments involving Centropages hamatus (Fig. 1B). FP length is an indication of break-up or ingestion, and the 2 treatments involving C. hamatus resulted in FP of similar length, although with higher variability in the Centropages treatment. This was also reflected in the fraction of fragmented FP, where on average $( \pm 1 \mathrm{SD})<94.7 \pm$ $3 \%$ broken FP were found after incubation with $C$. hamatus, compared to an average of $81 \pm 3 \%$ and 43 $\pm 8 \%$ in the dinoflagellate treatment and control, respectively (Fig. 1C). With regard to fragmentation, the control group (FP in FSW) was significantly different from all other treatments (paired samples $t$-test, $\mathrm{p}<0.004)$.

To each bottle, we added 80 intact FP, corresponding to $13.6 \mu \mathrm{g}$ POC. After $48 \mathrm{~h}$ of incubation, the average $( \pm \mathrm{SD})$ recovery of pellets in the FSW treatment was $12.6 \pm 0.5 \mu \mathrm{g} \mathrm{C}$, corresponding to a daily carbon loss of $0.5 \mu \mathrm{g} \mathrm{C}$. In the dinoflagellate treatment, $9.6 \pm 0.4 \mu \mathrm{g} \mathrm{C}$ was recovered, and the daily carbon loss was $2 \mu \mathrm{g} \mathrm{C}$. Only $4.5 \pm 1.8 \mu \mathrm{g} \mathrm{C}$ was left at $t_{48}$ in the Centropages treatment, but even less, $1.5 \pm$ $0.4 \mu \mathrm{g} \mathrm{C}$, was recovered in the combined dinoflagellates + Centropages treatment (Fig. 2). The percentage reduction in FPC after $48 \mathrm{~h}$ was $88 \%$ in the dinoflagellate + Centropages, $65 \%$ in the Centropages treatment and $24 \%$ in the dinoflagellate treatment. Daily degradation rates $(r$, average \pm SD) were $0.04 \pm$ $0.03 \mathrm{~d}^{-1}$ for FP in FSW, $0.18 \pm 0.03 \mathrm{~d}^{-1}$ for FP with dinoflagellates, $0.60 \pm 0.04 \mathrm{~d}^{-1}$ for Centropages and $1.12 \pm 0.21 \mathrm{~d}^{-1}$ for the FP incubated with dinoflagel-

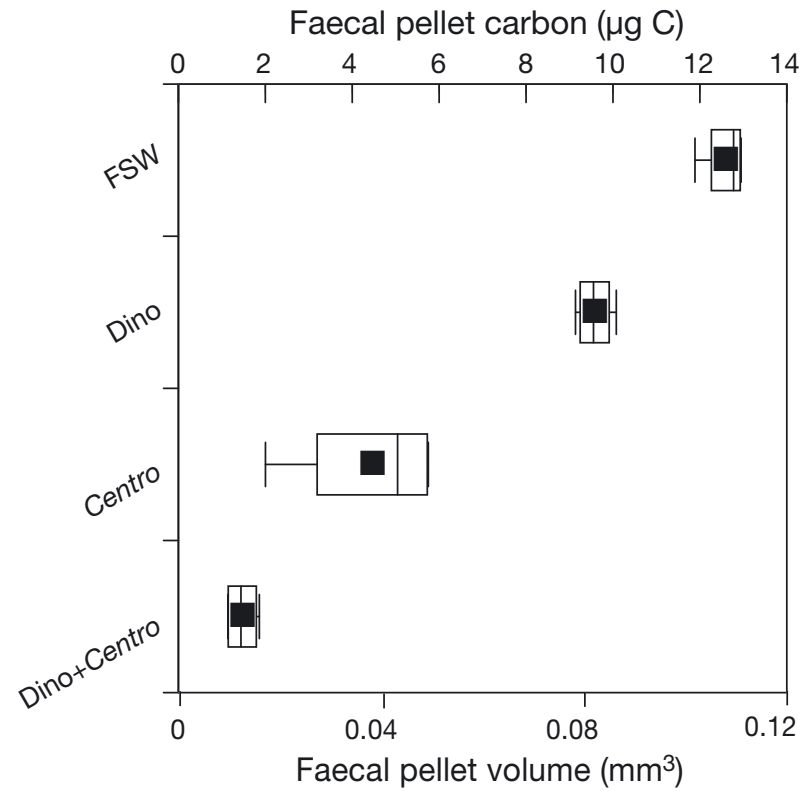

Fig. 2. Total Calanus spp. faecal pellet volume $\left(\mathrm{mm}^{3}\right)$ and carbon ( $\mu \mathrm{g} \mathrm{C}$ ) after $48 \mathrm{~h}$ incubation in filtered seawater (FSW), dinoflagellates (Dino), Centropages hamatus (Centro) and dinoflagellates $+C$. hamatus (Dino+Centro)

lates and Centropages (Fig. 3). Hence, the degradation rate in the treatment combining Centropages and dinoflagellates was $38 \%$ higher than the sum of all individual treatments. FP degradation rates from all treatments were significantly different from the degradation rate of FP in FSW (paired samples $t$-test, $\mathrm{p}<0.02$ ).

The carbon-specific respiration (average $\pm \mathrm{SD}$ ) of FP in FSW was $0.04 \pm 0.003 \mathrm{~d}^{-1}$ and was $0.052 \pm$ $0.011 \mathrm{~d}^{-1}$ for FP in water from the chl a max (Fig. 3). 


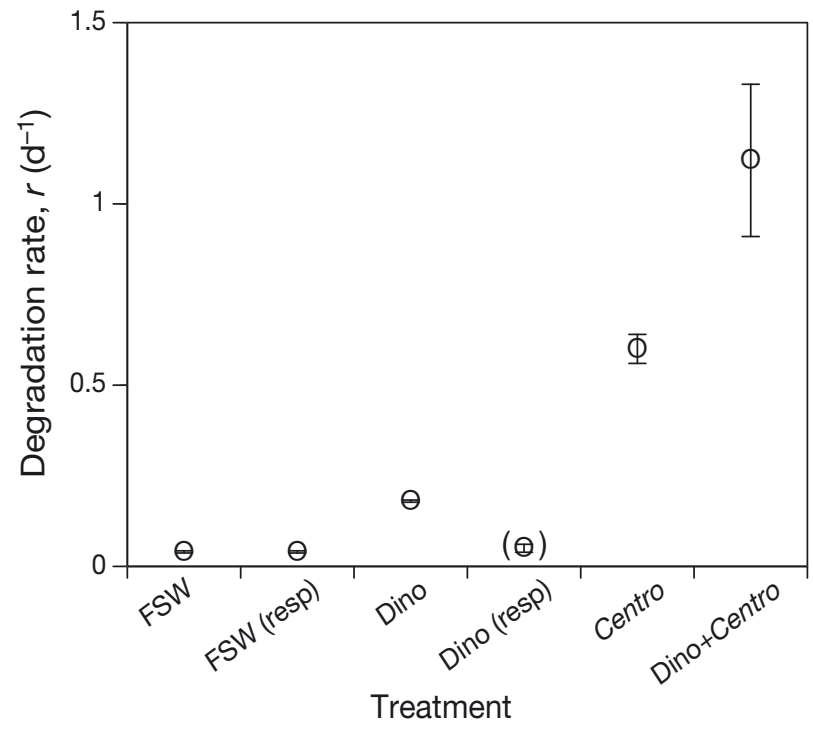

Fig. 3. Degradation rates $\left(r, \mathrm{~d}^{-1}\right)($ mean $\pm \mathrm{SD})$ calculated from microscopic counts and carbon-specific respiration (resp) of Calanus spp. faecal pellets in different treatment groups. FSW: filtered seawater; Dino: dinoflagellates; Centro: Centropages hamatus

\section{DISCUSSION}

The experiments revealed that dinoflagellates had a significant effect on FP degradation $\left(r=0.18 \mathrm{~d}^{-1}\right)$, but that $C$. hamatus were 3 -fold more efficient $(r=$ $0.60 \mathrm{~d}^{-1}$ ) in terms of degradation rates. Even more efficient was the concerted action of both dinoflagellates and $C$. hamatus $\left(r=1.12 \mathrm{~d}^{-1}\right)$, causing a $38 \%$ increase in FP degradation compared to the additive effects of the individual treatments.

An exponential function was chosen to describe FP degradation rates in this experiment, according to Poulsen \& Iversen (2008). It should be noted that degradation rates can also be estimated in terms of daily carbon-specific degradation rates or daily loss rates and that these methods indicate lower degradation rates and no additive effect of copepods and dinoflagellates in our experiment. However, these approaches do not account for a changing FP concentration and hence a decreasing encounter rate between the prey organisms and the FP during incubation. Therefore, in our experimental design with $48 \mathrm{~h}$ incubation time, we believe that the exponential function best describes the degradation of FP.

The total volume of FP added to each experimental bottle in the degradation experiment was $0.232 \mathrm{~mm}^{3}$ FP $l^{-1}$. This is within the range of in situ concentrations documented in Balsfjord, northern Norway (up to $0.11 \mathrm{~mm}^{3} \mathrm{FP} \mathrm{l}^{-1}$; Wexels Riser et al. 2010) and on the northern Norwegian Shelf (up to $0.36 \mathrm{~mm}^{3} \mathrm{l}^{-1}$; Wassmann et al. 1999). During the period of our experiments, the abundance of Centropages spp. copepodites (including both C. hamatus and C. typicus) in the surface waters of Gullmarsfjorden ranged from approximately 1.1 to 2.7 individuals (ind.) $\mathrm{l}^{-1}$ (M. Koski pers. comm.). The copepod concentration of 10 ind. $\mathrm{l}^{-1}$ used in our experiments is thus higher than the in situ concentration of Centropages spp. On the other hand, the total concentration of calanoid copepods in the surface layer ranged from about 10 to 33 ind. $\mathrm{l}^{-1}$ (M. Koski pers. comm.). Our experimental concentration of copepods is therefore within natural ranges of copepods found during summer in Gullmarsfjorden, although higher than for Centropages spp. specifically. We believe that the encounter rates between pellets and degrading organisms in our experimental set-up were realistic.

\section{Bacteria and dinoflagellates}

This study combined 2 approaches to measure FP degradation by organisms $<180 \mu \mathrm{m}$ : measurement of FP disappearance by microscopy, and measurement of carbon degradation through respiration. In $0.2 \mu \mathrm{m}$ FSW, both approaches gave similar FP degradation rates: $0.04 \mathrm{~d}^{-1}$. This low rate likely represents FP degradation by the bacteria present in the FP matrix. However, these rates are lower than previously reported degradation rates of $0.15 \mathrm{~d}^{-1}$, obtained under similar conditions (in terms of temperature and copepod food) but for FP about one-tenth the size (Ploug et al. 2008) and for sinking aggregates and FP (Iversen \& Ploug 2010). This indicates that small FP are more rapidly degraded by bacteria than large FP and hence suggests a positive correlation between high FP surface:volume ratio and greater relative importance of bacterial degradation (Hansen et al. 1996). On the other hand, comparatively high respiration rates, 101 (range 50 to 211) pmol $\mathrm{O}_{2} \mathrm{~d}^{-1} \mathrm{FP}^{-1}$, were found by Köster \& Paffenhöfer (2013) on larger FP produced by Eucalanus pileatus (FP volume: $2 \times$ $10^{6}$ to $4 \times 10^{6} \mathrm{\mu m}^{3}$ ). These rates are approximately 4 fold higher than the respiration rates measured in our experiment, $24 \mathrm{pmol} \mathrm{O} \mathrm{d}^{-1} \mathrm{FP}^{-1}$. However, the rates reported by Köster \& Paffenhöfer (2013) were measured at a higher temperature $\left(22^{\circ} \mathrm{C}\right)$ and shorter incubation time $(6 \mathrm{~h})$ than was used in our experiment. Despite differences in the measured degradation rates of copepod FP, it is apparent that FP degradation due to respiration is relatively low. This conclusion was also reached by Lampitt et al. (1990), 
who found that the rate of microbial (bacteria and protozoa) degradation was low and unlikely to cause significant destruction of intact pellets within their residence time in the water column. We believe that this is especially relevant for large FP, although small FP or FP fragments with higher residence time in the surface would likely be more susceptible to bacterial degradation.

Heterotrophic and mixotrophic dinoflagellates are raptorial feeders and capable of feeding on prey particles from 3 to $400 \mu \mathrm{m}$ in length (Hansen et al. 1994, Hansen \& Calado 1999). It has been demonstrated that several phagotrophic dinoflagellates are capable of utilising FP produced by Acartia tonsa as a source of food (Poulsen et al. 2011). The Calanus pellets utilised in our experiments had an average length of $466 \pm 90 \mu \mathrm{m}$, and Poulsen et al. (2011) suggested that FP $>400 \mu \mathrm{m}$ are too large for dinoflagellates to feed upon. However, the measured degradation rate by dinoflagellates in our experiment, $0.18 \mathrm{~d}^{-1}$, suggests that FP > $400 \mu \mathrm{m}$ may also be grazed by dinoflagellates. However, the increased FP degradation effect that was measured when dinoflagellates and $C$. hamatus were incubated together suggests that FP degradation by dinoflagellates is more efficient when large filter feeders break up FP into smaller pieces.

The C-specific respiration of FP by dinoflagellates $\left(0.052 \mathrm{~d}^{-1}\right)$ did not correspond to the FP-degradation rates of dinoflagellates as obtained by microscopy $\left(0.18 \mathrm{~d}^{-1}\right)$. In fact, the $\mathrm{C}$-specific respiration rate from the dinoflagellates was only slightly higher than the rate obtained in FSW (Fig. 3). We suggest that this is an artefact related to the small volume of respiration vials $(4 \mathrm{ml})$, leading to extremely low abundance of dinoflagellates in each vial. In a recent study quantifying respiration rates from dinoflagellates, a concentration of about 3000 ind. $\mathrm{ml}^{-1}$ was utilised (Calbet et al. 2013), while the natural concentration in our respiration vials was only 5 to 6 ind. $\mathrm{ml}^{-1}$ (a total of 20 to 24 individuals in each of the $4 \mathrm{ml}$ vials). The FP degradation as calculated by respiration of dinoflagellates in this experiment is therefore considered uncertain. However, the low dinoflagellate respiration rates do not impact the overall conclusions from this study.

\section{Centropages hamatus}

In the bottles containing $5 \mathrm{C}$. hamatus, an average of $9.1 \mu \mathrm{g} \mathrm{C}$ was lost during $48 \mathrm{~h}$ incubation, equal to $0.91 \mu \mathrm{g} \mathrm{C}$ ind. ${ }^{-1} \mathrm{~d}^{-1}$. Is this amount of carbon likely to cover the daily carbon demand of adult $C$. hamatus?
The respiration rate of an adult $C$. hamatus with a $\mathrm{C}$ content of $5 \mu \mathrm{g}$ is $\sim 1.4 \mu \mathrm{O} \mathrm{O}_{2} \mathrm{~d}^{-1}$, or $0.44 \mu \mathrm{g} \mathrm{C} \mathrm{d}^{-1}$ at $10^{\circ} \mathrm{C}$ (Lampitt et al. 1990 and references therein). This implies that the copepods in our experiment could have covered their $\mathrm{C}$-demand for basic metabolism by feeding on FP. The degradation rate of FP was $38 \%$ higher in the combined dinoflagellate + Centropages treatment compared to the sum of degradation rates from dinoflagellates and Centropages. This may have 2 possible explanations: (1) Centropages hamatus increased their feeding rates when prey particles other than FP were present (i.e. the dinoflagellates), causing greater ingestion of FP, or (2) there was a synergistic effect (i.e. the effect of the treatments combined is greater than the summed effects of each treatment alone) between the dinoflagellate and Centropages treatment. This could indicate that the feeding behaviour of the copepods was breaking pellets into smaller pieces, thus making them more susceptible to microbial degradation. We argue that the latter scenario is most likely. This is also supported by Lampitt et al. (1990), who noted that the peritrophic membrane of FP was missing after incubation with $C$. hamatus, making the FP more readily available for degradation by microorganisms.

\section{In situ degradation of copepod faecal pellets}

Degradation of copepod faecal pellets may be one of the most important regulating factors for the downward flux of particulate organic carbon (POC) and may contribute strongly to the biogeochemical cycling in the surface ocean (Wexels Riser et al. 2007). Several studies have focused on the degradation and vertical flux retention of small copepod FP (e.g. those produced by Acartia sp. or copepods of similar size) (Poulsen \& Kiørboe 2006, Ploug et al. 2008, Poulsen et al. 2011). However, a study from the Barents Sea demonstrated that the large FP produced by Calanus finmarchicus, C. glacialis and C. hyperboreus underwent considerable degradation within the upper $50 \mathrm{~m}$ of the water column (Wexels Riser et al. 2007). In the latter study, high concentrations of copepods were suggested to be the cause of high FP degradation, as microbial activity was regarded '....unlikely to affect FP removal/retention due to the high sinking speed of large FP, and consequently low residence time in the upper layers' (Wexels Riser et al. 2007, p. 728).

In this study, we demonstrated that large FP (length $\approx 450 \mu \mathrm{m}$ ) are in fact subject to grazing by 
dinoflagellates, as previously reported for smaller FP (Poulsen \& Iversen 2008) but not for large FP (Svensen et al. 2012). However, the present experiment was carried out over $48 \mathrm{~h}$, a time frame that might allow large and fast-sinking FP (50 to $300 \mathrm{~m}$ $\mathrm{d}^{-1}$ ) to escape the vertical zone where they would be exposed to grazing from dinoflagellates. The important process revealed in the present investigation is therefore the catalytic effect that copepod fragmentation may have on further degradation, by reducing the particle size and sinking speed. This process possibly increases the time-window during which the fragmented FP are exposed to microbial processes and dinoflagellate grazing. In this perspective, our experimental exposure time of $48 \mathrm{~h}$ for large FP degradation becomes relevant. This conclusion was also drawn from a previous experiment in which the combined effect of Calanus finmarchicus and microorganisms (mainly a combination of dinoflagellates and ciliates) significantly increased the degradation rate of similarly sized copepod FP after $48 \mathrm{~h}$ (Svensen et al. 2012). The Cspecific degradation rate found in the present experiment $\left(1.12 \pm 0.21 \mathrm{~d}^{-1}\right.$, average $\left.\pm \mathrm{SD}\right)$ is an order of magnitude higher than the rate of $0.12 \pm$ $0.03 \mathrm{~d}^{-1}$ obtained from a series of degradation experiments done at $15^{\circ} \mathrm{C}$ on sinking particles such as aggregates and FP (Iversen \& Ploug 2013). This illustrates the important role of mesozooplankton in the interaction effect with dinoflagellates.

The residence time of FP in the upper mixed layer determines the exposure time to potential degrading organisms and is therefore crucial for FP fate. Due to their high sinking speed, large FP tend to escape retention processes and degradation, resulting in an FP export dominated by large FP (Bathmann et al. 1987, Lane et al. 1994, Wexels Riser et al. 2008, Lalande et al. 2013). FP from small but highly abundant copepods are, in contrast, rarely observed in sediment traps (Lane et al. 1994, Wexels Riser et al. 2010). With comparable degradation rates on different particle types, the smallest FP would experience the highest $\mathrm{C}$-specific degradation given a longer degradation period, as also concluded by Shek \& Liu (2010).

However, it should be noted that the in situ sinking speed of FP may differ considerably from that obtained from laboratory measurements or estimated from pellet density (e.g. Komar et al. 1981). In a study done in surface waters off southern California, up to $40 \%$ of the crustacean pellets found in the upper $20 \mathrm{~m}$ were 4 to $10 \mathrm{~d}$ old, although estimated sinking rates of these pellets was 18 to $170 \mathrm{~m} \mathrm{~d}^{-1}$ (Alldredge et al. 1987). A long residence time, rather than changes in decomposition rate, was also considered to have the greatest impact on aggregate fragmentation and particle flux reduction in a more recent study from the same area (Goldthwait et al. 2005).

Longer residence time of large FP due to mixing, in concert with joint action from filter-feeding copepods (breaking large FP into smaller pieces) and dinoflagellates (feeding on FP fragments), may explain the common discrepancy between estimated and measured downward fluxes of large copepod FP (e.g. Wexels Riser et al. 2007). We therefore suggest that the 'coprophagous filter' may hold both a physical and a complex biological factor. By preventing loss of nutrients from the productive zone, thus facilitating a higher regenerated production, the synergetic retention filter provided by the mesozooplankton and microzooplankton on larger FP has an important ecological effect on the planktonic productivity. The role of mesozooplankton in vertical flux regulation is thus crucial, but complex, including (1) direct flux retention by removing small particles through grazing, (2) flux promotion by repackaging of small particles into larger particles through FP production, (3) direct flux retention through FP consumption or fragmentation and (4) indirect flux retention through concerted action with microzooplankton, causing enhanced degradation of FP.

Acknowledgements. We thank M. Koski and colleagues involved in the project 'The biological pump in the Nordic seas: Copepods and appendicularians as producers and consumers of sinking particles' (BioPump) for practical arrangements and for creating a stimulating working environment. We also thank Christian Wexels Riser for his valuable contribution to this study and Lena Seuthe for counting and identifying the protozooplankton. This work was carried out at Sven Lovén Center for Marine Research, University of Gothenburg, and was financed by Nordforsk (Biopump) and Tromsø Forskningsstiftelse, University of Tromsø (CONFLUX project).

\section{LITERATURE CITED}

Alldredge AL, Gotschalk CC, Macintyre S (1987) Evidence for sustained residence of macrocrustacean fecal pellets in surface waters off Southern California. Deep-Sea Res A 34:1641-1652

> Bathmann UV, Noji TT, Voss M, Peinert R (1987) Copepod fecal pellets: abundance, sedimentation and content at a permanent station in the Norwegian Sea in May/June 1986. Mar Ecol Prog Ser 38:45-51

Calbet A, Isari S, Martinez RA, Saiz E and others (2013) Adaptations to feast and famine in different strains of the marine heterotrophic dinoflagellates Gyrodinium dominans and Oxyrrhis marina. Mar Ecol Prog Ser 483:67-84 
Conley WJ, Turner TJ (1985) Omnivory by the coastal marine copepods Centropages hamatus and Labidocera aestiva. Mar Ecol Prog Ser 21:113-120

Goldthwait SA, Carlson CA, Henderson GK, Alldredge AL (2005) Effects of physical fragmentation on remineralization of marine snow. Mar Ecol Prog Ser 305:59-65

González HE, Smetacek V (1994) The possible role of the cyclopoid copepod Oithona in retarding vertical flux of zooplankton faecal material. Mar Ecol Prog Ser 113: 233-246

Gowing MM, Silver MW (1983) Origins and microenvironments of bacteria mediating fecal pellet decomposition in the sea. Mar Biol 73:7-16

Hansen B, Bech G (1996) Bacteria associated with a marine planktonic copepod in culture. 1. Bacterial genera in seawater, body surface, intestines and fecal pellets and succession during fecal pellet degradation. J Plankton Res 18:257-273

Hansen PJ, Calado AJ (1999) Phagotrophic mechanisms and prey selection in free-living dinoflagellates. J Eukaryot Microbiol 46:382-389

Hansen B, Bjørnsen PK, Hansen PJ (1994) The size ratio between planktonic predators and their prey. Limnol Oceanogr 39:395-403

> Hansen B, Fotel FL, Jensen NJ, Madsen SD (1996) Bacteria associated with a marine planktonic copepod in culture. 2. Degradation of fecal pellets produced on a diatom, a nanoflagellate or a dinoflagellate diet. J Plankton Res 18: 275-288

Iversen MH, Ploug H (2010) Ballast minerals and the sinking carbon flux in the ocean: carbon-specific respiration rates and sinking velocity of marine snow aggregates. Biogeosciences 7:2613-2624

Iversen MH, Ploug H (2013) Temperature effects on carbonspecific respiration rate and sinking velocity of diatom aggregates-potential implications for deep ocean export processes. Biogeosciences 10:4073-4085

> Iversen MH, Poulsen LK (2007) Coprorhexy, coprophagy, and coprochaly in the copepods Calanus helgolandicus, Pseudocalanus elongatus, and Oithona similis. Mar Ecol Prog Ser 350:79-89

Jacobsen TR, Azam F (1984) Role of bacteria in copepod fecal pellet decomposition-colonization, growth-rates and mineralization. Bull Mar Sci 35:495-502

> Jumars PA, Penry DL, Baross JA, Perry MJ, Frost BW (1989) Closing the microbial loop: dissolved carbon pathway to heterotrophic bacteria from incomplete ingestion, digestion and absorption in animals. Deep-Sea Res A 36: 483-495

Komar PD, Morse AP, Small LF, Fowler SW (1981) An analysis of sinking rates of natural copepod and euphausiid fecal pellets. Limnol Oceanogr 26:172-180

Köster M, Paffenhöfer GA (2013) Oxygen consumption of fecal pellets of doliolids (Tunicata, Thaliacea) and planktonic copepods (Crustacea, Copepoda). J Plankton Res 35:925-926

Lalande C, Bauerfeind E, Nothig EM, Beszczynska-Moller A (2013) Impact of a warm anomaly on export fluxes of biogenic matter in the eastern Fram Strait. Prog Oceanogr 109:70-77

- Lampitt RS, Noji T, von Bodungen B (1990) What happens to zooplankton faecal pellets? Implications for material flux. Mar Biol 104:15-23

> Lane PVZ, Smith SL, Urban JL, Biscayes PE (1994) Carbon flux and recycling associated with zooplanktonic fecal pellets on the shelf of the Middle Atlantic Bight. DeepSea Res II 41:437-457

> Menden-Deuer S, Lessard EJ (2000) Carbon to volume relationships for dinoflagellates, diatoms, and other protist plankton. Limnol Oceanogr 45:569-579

Noji T (1991) The influence of macrozooplankton on vertical particulate flux. Sarsia 76:1-9

Parsons TR, Maita Y, Lalli CM (1984) A manual of chemical and biological methods for seawater analysis. Pergamon Press, Oxford

Ploug H, Iversen MH, Koski M, Buitenhuis ET (2008) Production, oxygen respiration rates, and sinking velocity of copepod fecal pellets: Direct measurements of ballasting by opal and calcite. Limnol Oceanogr 53: 469-476

Poulsen LK, Iversen MH (2008) Degradation of copepod fecal pellets: key role of protozooplankton. Mar Ecol Prog Ser 367:1-13

Poulsen LK, Kiørboe T (2005) Coprophagy and coprorhexy in the copepods Acartia tonsa and Temora longicornis: clearance rates and feeding behaviour. Mar Ecol Prog Ser 299:217-227

> Poulsen LK, Kiørboe T (2006) Vertical flux and degradation rates of copepod fecal pellets in a zooplankton community dominated by small copepods. Mar Ecol Prog Ser 323:195-204

> Poulsen LK, Moldrup M, Berge T, Hansen PJ (2011) Feeding on copepod fecal pellets: a new trophic role of dinoflagellates as detritivores. Mar Ecol Prog Ser 441:65-78

Reigstad M, Wexels Riser C, Svensen C (2005) Fate of copepod faecal pellets and the role of Oithona spp. Mar Ecol Prog Ser 304:265-270

> Renaud PE, Morata N, Ambrose WG, Bowie JJ, Chiuchiolo A (2007) Carbon cycling by seafloor communities on the eastern Beaufort Sea shelf. J Exp Mar Biol Ecol 349: 248-260

> Saage A, Vadstein O, Sommer U (2009) Feeding behaviour of adult Centropages hamatus (Copepoda, Calanoida): functional response and selective feeding experiments. J Sea Res 62:16-21

> Shek L, Liu HB (2010) Oxygen consumption rates of fecal pellets produced by 3 coastal copepod species fed with a diatom Thalassiosira pseudonana. Mar Pollut Bull 60: 1005-1009

Svensen C, Nejstgaard JC (2003) Is sedimentation of copepod faecal pellets determined by cyclopoids? Evidence from enclosed ecosystems. J Plankton Res 25: 917-926

Svensen C, Wexels Riser C, Reigstad M, Seuthe L (2012) Degradation of copepod faecal pellets in the upper layer: role of microbial community and Calanus finmarchicus. Mar Ecol Prog Ser 462:39-49

Tiselius P, Jonsson PR (1990) Foraging behavior of six calanoid copepods: observations and hydrodynamic analysis. Mar Ecol Prog Ser 66:23-33

> Turner JT (1979) Microbial attachment to copepod fecal pellets and its possible ecological significance. Trans Am Microsc Soc 98:131-135

Turner JT (2002) Zooplankton fecal pellets, marine snow and sinking phytoplankton blooms. Aquat Microb Ecol $27: 57-102$

Wassmann P, Hansen L, Andreassen IJ, Wexels Riser C, Urban-Rich J (1999) Distribution and sedimentation of faecal pellets on the Nordvestbanken shelf, northern Norway, in 1994. Sarsia 84:239-252 
Wexels Riser C (2007) Fate of zooplankton faecal pellets in marine ecosystems: export or retention? $\mathrm{PhD}$ dissertation, UiT The Arctic University of Norway, Tromsø

Wexels Riser C, Reigstad M, Wassmann P, Arashkevich E, Falk-Petersen S (2007) Export or retention? Copepod abundance, faecal pellet production and vertical export in the marginal ice zone through snap shots from the northern Barents Sea. Polar Biol 30:719-730

Editorial responsibility: Anna Pasternak, Moscow, Russian Federation
Wexels Riser C, Wassmann P, Reigstad M, Seuthe L (2008) Vertical flux regulation by zooplankton in the northern Barents Sea during Arctic spring. Deep-Sea Res II 55: 2320-2329

Wexels Riser C, Reigstad M, Wassmann P (2010) Zooplankton-mediated carbon export: a seasonal study in a northern Norwegian fjord. Mar Biol Res 6: $461-471$

Submitted: December 9, 2013; Accepted: July 29, 2014 Proofs received from author(s): November 13, 2014 